\title{
A theory of instrumental and existential rational decisions: Smith, Weber, Mauss, Tönnies after Martin Buber
}

\author{
Elias L. Khalil ${ }^{1}$ (D) $\cdot$ Alain Marciano ${ }^{2}$ \\ Published online: 7 September 2020 \\ (C) The Author(s) 2020
}

\begin{abstract}
This paper proffers a dialogical theory of decision-making: decision-makers (DMs) are engaged in two modes of rational decisions, instrumental and existential. Instrumental rational decisions take place when the DM views the self externally to the objects, whether goods or animate beings. Existential rational decisions take place when the DM views the self in union with such objects. While the dialogical theory differs from Max Weber's distinction between two kinds of rationality, it follows Martin Buber's philosophical anthropology. The paper expounds the ramifications of the dialogical theory in understanding structures of exchange considering assessments of diverse thinkers.
\end{abstract}

Keywords Corporeal utility · Transcendental utility · Obligation · Duty · Motive of exchange $\cdot$ Context of exchange $\cdot$ Altruism/aid $\cdot$ Self-interest/contract · Geniality/ friendship · Camaraderie/grant · Distinction/status

\section{Introduction}

How and how effectively organizations function depends on how the respective members of the organization behave given the context of transactions and social goals that organizations set up. This is not a particularly new insight. Indeed, the literature across social theory, behavioral decision theory, behavioral economics, social exchange theory, and organization theory has largely emphasized that the prosocial behavior of members matters for the functionality of organizations (e.g., Homans 1961; Blau 1974; Coleman 1990; Etzioni 1986; Granovetter, 1973; Bowles and Gintis 2002; Brief and Motowidlo 1986; Bowler and Brass 2006; De Dreu 2006; De Dreu and Nauta 2009; Ehrhart and Naumann 2004; Grant 2008; Meglino and Korsgaard 2004, 2006; Michel 2017). This wide-ranging literature commonly draws a line between behaviors that are self-regarding as opposed to other-regarding. While the self/other juxtaposition has been useful in delineating self-interest from other-interest (i.e., altruism), the juxtaposition has led generally to the hegemony of

Extended author information available on the last page of the article 
a narrow twofold taxonomy in the social sciences and, particularly, in economics (see Khalil and Marciano 2021).

The canonical expression of this twofold taxonomy in economics is the oftquoted phrase of Adam Smith from the outset of his Inquiry into the Nature and Causes of the Wealth of Nations, concerning the self-interest motive of marketcentered transactions with the butcher, the brewer, or the baker:

It is not from the benevolence of the butcher, the brewer, or the baker, that we expect our dinner, but from their regard to their own interest. We address ourselves, not to their humanity but to their self-love, and never talk to them of our own necessities but of their advantages. Nobody but a beggar chuses to depend chiefly upon the benevolence of his fellow citizens (Smith 1976b, pp. 26-27).

With this, Smith identifies two structures of transactions:

1. the self-interest motive and its contract context;

2. the altruism motive and its aid context.

Of course, for scholars of Smith (see for example Khalil 1990, 1996, 2017), the motivations that Smith has unraveled are more complicated and varied than this dichotomy. Actually, the set of motivations that Smith has uncovered are the grits of the modern fields of behavioral economics and social psychology. What matters for this paper is not what Smith actually believed, but how Smith's twofold taxonomy in the above quote became entrenched in economic theory. Namely, economic theory became limited, especially at the hands of Gary Becker (1981), to the broad category "interest" or, equivalently, "wellbeing": either "self-interest" when the objective of the decision-maker (DM) is own-consumption, or "altruism" when the objective of the DM is the other-consumption whose interest enhances the DM's utility. Despite the differences between these two varieties of interest, they need not be dichotomous. In fact, they are pecuniary motives lying along a continuum that aims to maximize what this paper calls "corporeal utility" (see Khalil 1990). The DM satisfies her own corporeal utility or the corporeal utility of others, depending on the relative costs. Whether the DM is pursuing self-interest or other-interest (altruism), the DM is engaged in what is called here "instrumental rational decision." It is called "instrumental" because the DM stands externally to her own pecuniary satisfaction as well as externally to the pecuniary satisfaction of the other.

As insightful Smith's twofold taxonomy is, it remains limited to instrumental rational decision (Khalil and Marciano, 2018). This paper proffers that there are other motives that go beyond the satisfaction of interest, whether it is self-interest or other-interest. Such motives consist broadly of the longing for friendship, community, and distinction of achievement. Organization theory and the field of organizational behavior literature have discussed the longing for friendship, the aching for community, and the desire of distinction (e.g., Rocha and Ghoshal, 2006; Tasselli 2019). 
The motives to satisfy longing for friendship, community, and distinction are also regulated by rational choice as shown below, but this should not entail that they are pecuniary in the sense of belonging to corporeal utility. To see why, we need to question the assumption, so common in the literature, that rational choice is limited to corporeal utility. It is so common to suppose that if a theory uses the rational choice approach, it then reduces all costs and benefits to the corporeal dimension. This common supposition has caused a great hinderance to the advancement of a more generalized theory of human behavior. This paper expressly employs the separation of the rationality principle from the utility concept or, more generally, the pursuit of ends or products. We define rational choice as applicable to any calculation, not limited to corporeal utility. Rational choice also applies to motives listed above that concern existential ends, what is called here "transcendental utility." In each respective section below, this paper shows how the rational choice principle is pertinent to existential ends.

Existential ends transcend the corporeal self-i.e., a self that is defined by the biological skin-to fuse with others and produce another kind of pleasure, transcendental utility. The DM promotes her own transcendental utility when the DM is engaged in what is called here the "existential rational decision." In this mode, the DM satisfies at least three existential motives:

1. the geniality motive and its friendship or companionship context;

2. the camaraderie motive and its grant context;

3. the distinction motive and its status context.

This paper effectively proposes a dialogical theory of rational decisions: decisions can be either instrumental or existential. The instrumental rational mode of decisions gives rise to Smith's two motives: self-interest and other-interest (altruism). The existential rational mode of decisions gives rise to the three motives: geniality, camaraderie, and distinction. Section 2 links the three motives with Smith's dichotomy via the philosophical anthropology of Martin Buber and shows how it differs from Max Weber's notion of rationality. Sections 3, 4, and 5 discuss successively the three motives and their corresponding three structures that typify the existential decision mode of action. Section 6 concludes.

\section{Dialogical theory: Buber after Weber}

This paper considers two kinds of decisions, viz., the instrumental and the existential, as rational. The basic premise of rationality is that DMs are sensitive to costs such that they are ready to adjust behavior in light of changes in the budget constraint. Of course, to be sensitive one has to make assumptions about the consistency of the underlying preferences-which we need not explore here (see Kreps 2013, chs. 1-2). And DMs respond to costs when they are involved in instrumental decision-making and, somewhat differently, when they are involved in existential decision-making. That is, the fact that the DM undertakes a calculation, irrespective of whether the objective utility is corporeal or transcendental, the two decisions can be considered rational. 
The two proposed kinds of rationality are unrelated to Weber's famous distinction between "value rational" action and "instrumentally rational" action. As Weber states his famous distinction:

Social action, like all action, may be oriented in four ways. It may be:

1. instrumentally rational (zweckrational), that is, determined by expectations as to the behavior of objects in the environment and of other human beings; these expectations are used as "conditions" or "means" for the attainment of the actor's own rationally pursued and calculated ends;

2. (2) value-rational (wertrational), that is, determined by a conscious belief in the value for its own sake of some ethical, aesthetic, religious, or other form of behavior, independently of its prospects of success (Weber 1978, pp. 24-25).

Weber continues to identify the two other actions: "affectual (especially emotional)" and "traditional, that is, determined by ingrained habituation." These two kinds of actions are related to the proposed "transcendental utility" conceptwhich bears on the issue of the "fusion with others" that lies behind "friendship" and "camaraderie" and is related to Weber's view of status and distinction that is discussed below. But this paper is not a paper on what Weber had thought, but rather one that aims to advocate the dialogical view as the proper entry point on thinking about rationality per se.

As such, Weber's taxonomy of four actions and in particular the first and second actions as independent of each other indicates that his "value-rational" category is not about the ranking of preferences as economists understand it. It is rather about action, and specifically "some ethical, aesthetic, religious, or other form of behavior" (see above quote). So, the DM in Weber's world takes some actions without regard to the instruments and the conditions, i.e., without regard for the costs.

Granted that Weber's usage of the term "rational" is multi-varied and has given rise to diverse interpretations (see Eisen 1978), still it has little to do with the standard definition of rationality. For Weber, an "instrumentally rational" action is one that involves costs and is independent of the other types of actions.

To reconstruct Weber's typology, Weber's "value-rational" and the other two actions (emotional and habitual) involve behavior without regard to costs. For Weber, the DM pays attention to costs only when the DM chooses the instruments to attain the already determined goal or value to pursue. However, according to the standard definition of rationality, the DM undertakes "value rational" action or any other type of action only in light of the considerations of the instruments and conditions, i.e., the costs. That is, any action irrespective of its content already implies costs. So, Weber's "value rational" category, at best identifies the preferences, while action can only take place once the instruments and conditions, i.e., the costs, are also attended.

By definition, rationality is choosing a benefit, which is not simply restricted to ethical value, in light of cost; what Weber must have meant by "means" and "conditions." So, Weber's "value rational" and "instrumentally rational" can make sense only as the two sides necessary for the same action. 
Put tersely, Weber's distinction is not a distinction between two kinds of rationality, but rather between two aspects of the same kind of rationality. In contrast, the dialogical view, viz., the distinction between "existential rationality" and "instrumental rationality," is indeed two different modes of decision delineated by the nature of the relation of the DM and the objects that concern the DM.

To make sense of the dialogical view, let us examine Martin Buber's approach (1970). To be clear, Buber wants to elucidate the nature of DM's relation to God. But his starting point is the DM's relation to objects in the terrestrial world, e.g., rocks, rivers, trees, birds, humans, and so on, without ever mentioning or alluding to God. This paper takes his entry point about the DM's relation with objects to show its dialogical nature, i.e., how it consists of two modes of action. As Table 1 shows, the DM relates to objects in the world along the instrumental and existential modes. Along the instrumental mode, the DM engages the self as a tool that also uses others (inanimate things and human collaborators) as tools to achieve an end. As such, the DM is external to the objects of the world. Along the existential mode, in contrast, the DM engages the self as a subject that fuses with others as subjects to produce an end. When the DM ("I") acts as a tool to engage with others as tools (objects), the decision mode of action is instrumental. When the DM ("I") acts as a subject to engage with others as subjects, the decision mode of action is existential. Both kinds of actions are legitimate and necessary - as long as the intentions of the engaged DMs are transparent to each other.

In the instrumental rational decision mode of action, the product is corporeal utility, which exactly equals the economist's concept of utility. In the existential rational decision mode of action, the product is transcendental utility, which equals the pleasure and warmth of having friends, community, or belonging to a group that is larger than one's biological self. The reason that transcendental utility cannot be reduced to the economist's utility category, i.e., to corporeal utility, is simple. In corporeal utility, the DM relates to things, including humans, as external objects. In transcendental utility, the DM can experience such utility only if he or she lets the self to amalgamate with the selves of the others. The pleasure of friendship can arise only if the two selves transcend their view of each other as instruments and rather engage in a conversation, which is the convergence of their pleasures and anguish.

To clarify, the proposed dialogical approach is not a theory of consumption as opposed to a theory of production. It rather supersedes the production/consumption distinction. It is about how a person relates to objects in the world and uses them-

Table 1 Reconstructing Buber's dialogical theory

\begin{tabular}{|c|c|c|c|c|}
\hline & Self & Others & Mode of action & Product \\
\hline \multirow[t]{2}{*}{$\begin{array}{l}\text { Decision-maker } \\
\text { (Buber's “I") }\end{array}$} & $\begin{array}{l}\text { The decision- } \\
\text { maker as tool }\end{array}$ & $\begin{array}{l}\text { Tools (Buber's } \\
\text { "it") }\end{array}$ & $\begin{array}{l}\text { Instrumental rational } \\
\text { decision (Buber's “I-it”) }\end{array}$ & $\begin{array}{l}\text { Corporeal } \\
\text { utility }\end{array}$ \\
\hline & $\begin{array}{l}\text { The decision- } \\
\text { maker as } \\
\text { subject }\end{array}$ & $\begin{array}{l}\text { Subjects } \\
\text { (Buber's } \\
\text { "thou") }\end{array}$ & $\begin{array}{l}\text { Existential rational } \\
\text { decision } \\
\text { (Buber's "I-thou") }\end{array}$ & $\begin{array}{l}\text { Transcendental } \\
\text { utility }\end{array}$ \\
\hline
\end{tabular}


irrespective of whether the person is engaged in production or engaged in consumption. Let us use the simplified case of the employment of tools and raw materials to make a door and enjoy it. This case is simplified, given that the modern division of labor breaks this process into many steps that are mediated via market exchange. Ignoring the division of labor, which comes at secondary and tertiary approximations, the dialogical approach distinguishes between two ways in which the person relates to both the production process and the final consumption. The person seeks lumber, cutting tools, nails, varnish, and so on, to produce the door and to enjoy the utility of the door for many years. Along the instrumental axis, the person follows precise engineering steps on how to cut lumber and use the nails to make the door and to enjoy the door as a protection from, for instance, the elements of nature. In contrast, along the existential axis, the same person during the same process imagines how the door will afford warmth and how it will enhance belonging to the place. Such an imagination influences improvisation during production, such as adding decorative twists to the door.

This paper, though, goes beyond Buber's instrumental/existential dialogical framework in at least five ways. First, this paper rehabilitates the importance of the I-it mode of action, which is the focus of standard economics. In Buber's thought, this decision mode took a secondary role, as if it is a non-genuine, if not a crippled relation. The secondary role that Buber accords the I-it relation may explain why he immersed himself in Jewish mysticism in his later writings (Wood 1969; Katz 1985).

Second, the I-it relation includes the DM's manipulation of tools to fix, e.g., a machine or to transport the DM to another location. It also includes how the DM coordinates with collaborators on how to carry out a plan concerning the division of labor or the production of a public good. ${ }^{1}$ This broad usage is consistent with Buber's (see Schilpp 1967; Wyschogrod 1967). This paper likewise does not restrict the I-thou relation to human-human fusion as in friendship. The DM can equally build a bond with a pet, an alley, a mountain, or even a toy.

Third, to many thinkers, Buber's dialogical framework intimates the Cartesian dichotomy: The DM pursues an interest to generate corporeal utility, while the DM pursues fusion with the objects to generate transcendental utility. The instrumental/ existential distinction advanced in this paper should not suggest, however, the Cartesian dichotomy. There need not be a Cartesian dichotomy in light of the fact that the transcendental utility is also subject to the discipline of the income/time constraint: one simply cannot pursue friendship and communal activities without attending to the limits posed by one's set of constraints. The DM has to allocate time and resources to each mode of action. The consequent two utilities must be traded at least in light of the budget constraint, irrespective of the changes in relative prices. Only through an over-arching utility, the DM can decide how to allocate resources between the instrumental and existential ends that promote corporeal utility on one hand, and transcendental utility on the other.

\footnotetext{
1 This paper uses the term "goods" in the broadest sense to denote services, favors, debts, advocacy time, and so on.
} 
Fourth, this paper enriches the I-thou mode of action by identifying three varieties of transcendental utility, which correspond to the proposed three additional structures of exchange. Actually, there could be more than three. ${ }^{2}$ The most surprising of the three, which Buber neglects, is the ecstasy of striving and entering into a fusion of some imagined successful self, a hero or whoever seems to have distinguished him- or herself. Such transcendence engenders admiration of the distinguished, which acts as the origin of status and social stratification as this paper shows. This entails that social stratification expresses power and prestige, where such power and prestige need neither be exploitative nor oppressive but are rather demanded as an arena of human longing for distinction.

Fifth, in everyday life, it is not usual to see a pure structure. It is often the case that actual relationships, such as those between cohabitating partners that form a family, express mixed structures. Within the modern family-and, by extension, within kinship systems in less complex social formations-the structures are not easily differentiated. It is possible that two people can be business partners, friends, as well as involved in erotic love. Still, even in the most primitive social formation, where structures are combined, we still can identify the basic structures, whereas they take differentiated forms and separate institutions in modern complex social formations.

Given the fact that actual relations usually involve mixed structures, it is imperative to distinguish the pure form of each structure. The raison d'etre of this paper collapses if we take this fact to support the standard economist approach. This approach reduces all motives to a single, pecuniary utility function. Becker (1993), one of the major representatives of this approach, adds integrity, pride, love of family, altruism, and so on, along pecuniary utility. Such unidimensional view of utility allows for the smooth substitution of the different preferences, depending on the relative price and other constraints. This presents individual preferences as commensurable and therefore allows the aggregation of these preferences at the market level.

But this standard approach cannot easily provide an account of what happens in different and across contexts of exchange. And such account is imperative to explain several puzzles. Although the investigation of such puzzles falls outside the scope of this paper, it is sufficient to highlight a few of them. First, if the ingredients or motives are mixable, i.e., commensurable, what is the origin of taboos of trading sex, the right to vote, human kidneys, children-for-adoption, etc., as commodities? Second, why is it hard for people to quit the pursuit of distinction, and even supplant it or substitute it by admiring the successful, if such pursuit is pecuniary? Third, why is it distasteful to remind friends of the price of birthday gifts, etc. (see Khalil and Marciano 2018)? Fourth, why is it judged as distasteful for providing aid to help, e.g., the victims of floods under the pretense of altruism, when the supposed benefactor is motivated by private gain?

At the same time, we see that using our approach does not preclude the analysis of aggregated phenomena. After all, taboos and prohibitions of trading human

\footnotetext{
${ }^{2}$ One such structure can be erotic intercourse. Another can be spirituality, when Buber qualifies the thou as "eternal thou".
} 
kidneys and children-for-adoption are aggregate, macro phenomena. In addition, our approach can explain these phenomena, while the standard economist approach cannot do it easily, i.e., at first approximation.

\section{The geniality/friendship structure}

Sociologists have long noted the importance of friendship as they examined the bonds that hold social networks (Granovetter 1973, 1983; Etzioni 1988; Coleman 1990). Sociologists can be credited as the forerunners of the field of social networks, as they examined how weak and strong ties form the basis of trust that Coleman (1990) popularized with his stress on "social capital." The notion of social capital was further developed by political scientists such as Putman (1993, 2000), as he examined how social capital is conducive to the working of democracy.

In contrast, social psychologists have looked inward: how friendship nourishes psychological development and mental health (e.g., Suttles 1970; Spencer and Pahl 2006).

On the other hand, the focus on friendship has not reached the attention of economic theorists-except for the literature around trust, culture, and social capital with respect to economic growth (Guiso et al. 2004, 2006; Bowles and Gintis 2002; Granovetter 2005; Khalil 2003, 2012). One can generally state that decision theorists have not been able to adjust their framework to accommodate friendship. And when they do, as in the work of Gui and Sugden (2010, Introduction), they do not at first approximation distinguish friendship structure, based on geniality, from contractual structure, based on pecuniary interests. These theorists characterize almost all exchanged goods as "relational goods" to express how self-interest and friendship are mixed in everyday life (see also Gui 1996, 2000; Sugden 2005,2002; Bruni and Sudgen 2008). ${ }^{3}$

It is true that in everyday life contractual relations and geniality are mixed. As Folbre and Nelson (2000; see also Nelson 2005) demonstrate, caring and love play a role in the division of labor in the market, where women are over-represented in some professions such as teaching and nursing. even in industries that are far from teaching and nursing, contractual relations are mixed with geniality and kindness.

Ultimately, though, contractual relations are the core of many if not all industries. When the DM starts with the self-interest motive and enters contractual relations with others, the core of such relations is the self-interest motive. The enveloping or wrapping of the contractual relation with geniality and kindness comes at secondary if not at tertiary approximation.

This paper ignores the elaboration of contractual relation with geniality and kindness because the relation is ultimately contractual, while the geniality or

\footnotetext{
${ }^{3}$ Darwall (2011) also commits the same confusion that leads to the representation of instrumental transactions as if they are existential. Darwall calls any kind of fellow-feeling "second-person standpoint." For him, any fellow-feeling, which he calls "empathy," affords seeing the self from the second-person standpoint, the person towards whom one expresses fellow-feeling. But this confuses the caring for the interest of others, which satisfies corporeal utility and hence the subject of the instrumental decision mode, and the fusion of selves that defines friendship, which satisfies transcendental utility and hence the subject of the existential decision mode.
} 
kindness is rather a passing aspect of the relationship. The geniality or kindness is rather an elaboration of the contractual structure that a researcher may analyze at secondary and even at tertiary approximations.

Even if contractual structures are usually wrapped with friendship and geniality, we still need to separate them at first approximation. We still need to identify the different structures in their pure form following Buber's dialogical approach. Such an approach has many benefits. First, Buber's dialogical approach helps us avoiding the conflation of, e.g., intrinsic motivation with the desire for distinction (aspiration). It is too easy for non-standard economists (e.g., Frey 1997) to conflate intrinsic motivation with aspiration. Intrinsic motivation has affinity to formal contracts and promise making, where the actors feel formally obligated to deliver what was ex ante promised. In contrast, aspiration and the desire for distinction has affinity to existential motives in general.

Second, Buber's dialogical approach helps us eschewing the conception of altruism and justice as part of the geniality and kindness motive regulated by existential rational decision. They are rather aspects of pecuniary motive regulated by instrumental rational decision. The fact that the DM acts with fairness and acts according to altruism should not mean, given the proposed dialogical framework, that such acts are existential. In the act of justice, one usually abides by the rule of justice to avoid the suboptimal prisoners' dilemma outcome, which is a pecuniary Pareto suboptimal outcome. Also, in the act of altruism when one donates food to a starving family, one is motivated to satisfy hunger. Insofar as the act to satisfy one's own hunger is regarded as instrumental rational decision, why is it not so when one acts to satisfy the hunger of others?

To elaborate, if a theorist sees justice and altruism as ethical acts, he or she must see self-interest likewise. If a theorist identifies the instrumental rational decision mode of action merely with self-interest, such self-interest involves ethical judgments. Given that such involvement does not qualify the treatment of structures based on self-interest as part of the geniality structure, the structure involving acts of altruism and justice also does not qualify it as part of the geniality structure. ${ }^{4}$

The geniality motive, to start with, does not involve rational judgments regarding allocation of resources between the self and the other. Rather, when the geniality motive involves rational judgments, it is rather about the extent or degree of geniality. That is, even when the geniality motive is separate from corporeal utility, the geniality motive is regulated by rational choice insofar as it expresses

\footnotetext{
4 The fact that Smith's Theory of Moral Sentiments is about ethics and normative judgments does not entail that its main thrust is the existential decision mode of action and, hence, must be categorized as part of the geniality and kindness structure. The main trust of The Theory of Moral Sentiments is judgment of action in relation to self- and other-interests. It is true that Smith discusses existential mode of action at least twice. First, Smith explicitly analyzes friendship-and-love under the concept "mutual sympathy" (Smith 1976a, pp. 13-16, 31-34, 38-40). Second, Smith analyzes the desire for distinction under the concept "peculiar sympathy" (Smith 1976a, pp. 50-66). In these analyses, Smith even qualifies, as usual, these existential motives when he criticizes the excesses of friendship-and-love as well as the adulation of the rich-and-powerful. Still, as detailed elsewhere (Khalil 2020a), Smith does not incorporate these existential motives in his main thrust in The Theory of Moral Sentiments. His main trust is a theory of the two functions of the concept "sympathy," viz., the "propriety of action" function and the "merit of action” function (Smith 1976a, p. 92).
} 
friendship-and-love. The "impartial spectator," to use Adam Smith's expression for the fair judge, uses rational choice when he approbates the intensity of friendship or companionship of two people. Such friendship may become obsessive in the sense of hindering the emotional development of the partners involves. In this case, it evolves into possessiveness that limits, instead of furthering, the ability of the partners to undertake tasks, solve problems, invest in human capital, and become viable/healthy human beings. In such rational calibration, the cost-and-benefit is not corporeal. Rather, the benefit is the satisfaction of geniality, while the cost is emotional dependency that may hinder the development and functionality of the DM.

\section{Camaraderie/grant}

It is common that the DM starts a relationship of friendship, i.e., based on the geniality motive, and later develops a contractual relation that is based on the selfinterest motive. The outcome is a new structure which is neither pure friendship nor pure contract, but an amalgam of both. The new amalgamated motive is usually identified as "camaraderie" and its context is grant-giving or solidarity that involves helping others as friends and family.

The camaraderie structure differs from the situation mentioned above, viz., when the DM starts a relation with others on a contractual basis, but later solidifies it with geniality and kindness. This paper, as mentioned above, ignores this structure because the relation is ultimately contractual, and the geniality is rather passing. With camaraderie structure, the geniality and kindness are rather deep because the DM starts with geniality and only later supplements it with the self-interest motive.

The camaraderie amalgamated structure is actually a celebrated ethos in Australian culture and known as "mateship" (Dyrenfurth 2015; Ward 1958). Of course, camaraderie is not unique to any culture. Most if not all transcendental structures-from churches to philanthropies that distribute grants to different endeavors-fulfill the DM's amalgamated motives of friendship and self-interest as the basic camaraderie motive. Here, churches and philanthropies build a communal solidarity that satisfies one's need for belonging and friendship, on one hand, as well as one's need for help, on the other.

Kenneth Boulding is one of the few economists to recognize the camaraderie motive as the basis of communal solidarity. He calls this the "grants economy"where the DM meets his or her need for friendship and the grant affords economic help (Boulding 1973, 1982; Wray 1994).

It still behooves us at first approximation to distinguish friendship from grantgiving. Friendship concerns the DM's sense of emotional belonging, while the camaraderie satisfies such belonging as well as enhances the DM's budget constraint. Despite their slight difference, these two structures typify Buber's I-thou relation, i.e., the existential decision mode of action. There is no better place in the social sciences to demonstrate the existential decision mode of action than Mauss's discussion of the gift relation. 


\subsection{Starting with Marcel Mauss}

Members of families and communities do exchange goods according to Buber's I-it mode, i.e., according to the instrumental mode of actions of self-interest and altruistic motives. But they also exchange goods to cement the bond of the family or community. To analyze what is specific to families and communities, we need to introduce the camaraderie motive: the social or tribal instinct, the desire to live with others. Smith's twofold taxonomy at the outset of The Wealth of Nations is simply insufficient to account for camaraderie.

Armed only with a Smith-like twofold taxonomy, Bronislaw Malinowski (1922) found the exchanges among the Trobriand islanders difficult to understand. Given that most exchanges in these islands can neither be seen as pure gifts (aid) nor as contractual exchanges, Malinowski classified them as a "mixture"-and hence placed them along a scale of how far they are from two opposite poles: contract and aid.

This explains why Marcel Mauss, who is a sociologist, but regarded also as another father of anthropology, criticized Malinowski: classifying exchanges as "impure gifts" is misleading because it seems to imply that pure gift-exchange, as exemplified in the aid context, is the only true kind of gift. For Mauss, to embrace the idea of "impure gifts" entails that gift-exchanges in the grant context are adulterated. To put it differently, Malinowski's notion entails that the gift-exchange in the grant context is not a primitive, i.e. it can be decomposed into the more fundamental elements of benevolence and self-interest.

For Mauss, and as advocated in this paper, the gift-exchange in the grant context is both complex and primitive. It is complex because it entails the exchange of goods while also expressing camaraderie. It is primitive because it cannot be described, as Malinowski does, as being composed of separate motives. Rather, the motive to be part of a community is primitive, elemental; it cannot be decomposed into further elements.

The complex and primitive nature of grants, and of how gift-exchange expresses it, was one of the most important insights of Mauss' 1922 classic book, The Gift: Forms and Functions of Exchange in Archaic Societies. For Mauss, the giftexchange that constitutes the grant is the elemental foundation of the community. The grant context can be best understood as the context that hosts gift-exchange in Mauss's sense of the term ${ }^{5}$.

From his anthropological observations, Mauss concluded that a gift-exchange is never pure or free, in the sense that the receiver always has a duty to return another gift. The gift-exchange, in Mauss' sense, is a duty in the soft sense: it is neither

\footnotetext{
${ }^{5}$ Some anthropologists, such as Alain Testart (1998), criticized Mauss for excessive generalization, as they point out that people offer aid in modern societies, such as helping the needy, without any obligation in the formal sense nor duty in the informal sense of the needy person to reciprocate beyond saying, "Thank you." This is best documented in the famous study of Titmus (1970) about blood donation. The donors are motivated by benevolence, i.e. caring about the wellbeing of others. However, Testart's critique is not a serious critique once we limit Mauss's notion of the gift to the solidarity context, and then set it apart from the aid context that is grounded on benevolence. Once we limit Mauss' notion of the gift to the solidarity context, we can see why he approvingly quotes Radcliffe-Brown (see below).
} 
voluntary as in the case of gift-exchange in modern Western societies nor obligatory as in the case of formal promise that includes legally binding contract. This is what Mary Douglas, in her introduction to Mauss' essay, notes when reflecting on the early history of anthropology:

By ignoring the universal custom of compulsory gifts we make our own record incomprehensible to ourselves: right across the globe and as far back as we can go in the history of human civilization, the major transfer of goods has been by cycles of obligatory returns of gifts (quoted in Mauss 1990, p. x).

This paper uses the term "duty" to denote Mauss' term "obligatory returns of gifts," to indicate that the need to reciprocate is not in the formal or legal sense. In duty-bound exchanges, the organizing motive is neither "self-interest" in the juridical sense nor "altruism" in the sense of compassion and benevolence. The organizing principle is rather the desire to belong to a community, to something bigger than the self as defined by one's biological skin. Gift exchanges promote social bonding, where the participants experience the feeling of being "at home" with each other. For Mauss, a gift-exchange is conducted to solidify the sense of belonging, grant, or friendship between the giver and the receiver. The present carries the giver's active energy, which in turn possesses the beneficiary's attention and, hence, makes him want to act out of duty and reciprocate:

What imposes obligation in the present received and exchanged, is the fact that the thing received is not inactive. Even when it has been abandoned by the giver, it still possesses something of him. Through it the giver has a hold over the beneficiary just as, being its owner, through it he has a hold over the thief (Mauss 1990, p. 15).

Note again, the term "obligation" in the above quote conveys the sense of dutysince this paper restricts the term "obligation" to formal or legal blinding.

In her introduction, Douglas goes so far as to say that if a putative gift-exchange induced no duty to reciprocate, it would not be a gift: "A gift that does nothing to enhance solidarity is a contradiction" (quoted from Mauss 1990, p. x). This is true, though only within Mauss' narrow definition of the gift-i.e., as a gift-exchange that takes place in the grant context. Mauss might have gone too far in ruling out other meaning of the gift, the kind exchanged in the aid context. As shown in this paper, the aid context affords a meaning to the gift-exchange as solely concerning help and benevolence, without any further grant or community-based duties.

It could be said that the gift-exchange that characterizes the grant context has a superficial resemblance to the commodity exchange in the contract context. In both cases, the recipient is duty-required to reciprocate - and it might be the case that the reciprocation value may diverge from the original value. But reciprocity in the contract context has a radically different meaning from the kind of reciprocity seen in the grant context.

First, in the grant context, a returned gift cannot be considered as a payment in the same juridical sense of payment in the contractual exchange. On this point, the grant context resembles the aid context in the sense that the recipient is not (and cannot be) legally obliged to pay for the received good. Second, to emphasize this 
point, the reciprocated gift-exchange in the grant context usually has to be separated in time from the original gift-exchange to signal that it is not quid pro quo. ${ }^{6} \mathrm{Such}$ separation is not a necessary feature of exchange in the contract context. If a giftexchange within the grant context is returned simultaneously, the counter-giftexchange may signal that the exchange is contractual. This would annihilate the original gift-exchange, in the sense that the recipient of the counter-gift would perceive it as if it were a payment within the contract context. The recipient would feel disappointed, even hurt; they would feel that the other party was rejecting their overture to nurture a communal bond, solidarity between the two.

Put differently, an immediate counter-gift-exchange makes the giver of the counter-gift-exchange appear as if he is rejecting the grant context that was intended by the original gift-giver. This function of the exchange within the grant context sets it apart from exchanges in the other two contexts, aid and contract. In the aid context, there is no reciprocity and no counter-gift has to be given. In the contract context, the counter-gift would not be a separate exchange at all. It will be envisaged by the contract and would take place along the terms of the contract. The parties in the contract context consider the exchanged goods to be of equal value, exchanged simultaneously in the form of actual goods or with formal promises (debt-based contracts). This should not be the case in the grant context. When a counter-gift is offered, it must not usually be immediate to avoid sending the wrong signal.

The avoidance of the wrong signal is what is described by the British anthropologist, Alfred Radcliffe-Brown, also quoted by Mauss when he analyzed inter-group exchange in the Andaman Islands in 1906. These islanders exchanged a considerable volume of ochre and sea goods against the goods of the forest. And yet, despite the fact that the exchanged goods are considerable, they are not exchanged according to a contract. The objective of the gift-exchange is different:

... these presents do not serve the same purpose as commerce and exchange in more developed societies. The goal is above all a moral one, the object being to foster friendly feelings between the two persons in question, and if the exercise failed to do so, everything had failed (quoted in Mauss 1990, pp. 24-25).

Indeed, the objective of the gift-exchange in the grant context is different; the objective is a "moral one," to nurture the operative motive, viz. an amiable feeling that defines the community.

Cedrini et al. (2019) basically offer a similar view of Mauss' notion of the gift. They go further to argue that such a view resonates with Thorstein Veblen's (1934) characterization of market exchange, and can, in fact, serve as the foundation of non-neoclassical economics view of the role of institutions (see Hodgson 2000, 2003, 2006). Namely, for Mauss, all kinds of exchanges are governed by institutions where such institutions cohere social relations as basically aspects of a

\footnotetext{
${ }^{6}$ One might object that, in certain circumstances such as Christmas, gift-exchange is ritualized to the point of taking place at the very same moment. Still, the exchange is not quid pro quo because when one gives a gift during a Christmas party, it is not supposed to be given under the condition of payment, even when the reciprocation takes place in the same event.
} 
single social/communal process. The gift is a facilitator of camaraderie that combats the inner urges of envy, rivalry, and so on, among the members of the communityturning possible dark emotions via sacrifice and other rituals into communal bonds. This view of Mauss, which Cedrini et al. render truthfully, mirrors greatly Emile Durkheim's view, as Hart (2007) shows, namely, society consists basically of a single domain.

In contrast, this paper regards transactions as bifurcated along at least two domains: the instrumental-based exchanges that express self-interest and the existential-based exchanges that satisfy the need for communal solidarity, love, and so on. This paper finds Tönnies' view most promising in this regard.

\subsection{Back to Tönnies}

No other classical theorist has captured the grant context better than Tönnies (2001) in his Gemeinschaft and Gesellschaft, originally published in 1887, over 3 decades prior to Mauss' The Gift. Most academics, starting with Émile Durkheim, despite the continued protestation of Tönnies himself, interpreted Tönnies' twofold taxonomy as a dichotomy of two different modes of being that took the shape of two separate historical epochs or unrelated social structures: "community," Gemeinschaft, taken to epitomize hamlets and villages during medieval Europe, as opposed to "society," Gesellschaft, considered to exemplify modern civil society where the market is the driving force.

These academics came to wrongly view Tönnies' classic as being about the great transformation brought about the forces of the market, as forces that moved humans from "communities" to "societies." However, as Tönnies makes clear, even as early as in the introduction of the first edition, the two structures rather co-exist in the same and every social formation. That is, the hamlets and the bands of huntersand-gatherers have societal and communal structures. Likewise, the most modern advanced market-centered social formations have both structures. Every concrete structure, at every scale, contains elements of both pure structures. In this sense, Tönnies anticipates Buber's philosophical anthropology: both are modes of transactions that are intrinsic to being human.

In the introduction to the first edition, Tönnies provides the intellectual context that motivated him to distinguish "community" from "society" as ideal types. He says that he has grown dissatisfied with the ideologically driven debate between advocates of individualism, who want to promote reliance on the market, and the advocates of collectivism, who want to promote socialism. Tönnies argues that there is actually only individualism, but of two different kinds. As he elaborates in Book II, there is a DM characterized by "natural will" and there is a DM characterized by "rational will". The natural will is the "unselfconscious" kind from which community springs, while the rational will is the "selfconscious" kind from which society arises. For Tönnies, both ideal types are two poles of a continuum, and the task of empirical research is to identify how much closer a particular institution or social group is to one ideal type rather than the other. That is, these two ideal types do not express mutually exclusive social structures, whether separated historically or co-existing in formation. Rather, these two ideal types are mere "ingredients" 
that can be mixed in different proportions in all social structures within a formation or throughout history.

Our proposed grant/contract juxtaposition does not view social structures at first approximation as the mixing of ingredients, i.e., as the mixing of two poles that lie along a continuum. Still, the proposed juxtaposition or more broadly, the existential/ instrumental distinction, concurs with Tönnies: the two contexts of exchange should not entail two different societies, each mainly characterized by one but not the other. They rather coexist side-by-side in the same society. They may also depend on each other at a deeper level. But it is outside the scope of this paper to show how they are co-dependent. It is sufficient to state that at the apparent level, they are separate. Even, one could argue in simple, less complex societies, where the contexts of exchange are not instituted as entirely separate, clearly differentiable rituals, they still exist. That is, in such simple societies DMs can intuitively tell apart the different types of motives and hence, differentiate the different structures of exchange.

Each context invites a different motive, where the unity of the motive with its context characterizes the structure of exchange. Each structure stands independent of the other, at least at the conceptual level. One failing of Tönnies is that he supposed that these structures did not stand alone, but rather were entities spread along the same continuum. If this were the case, one entity could be putatively transformed into the other if some constitutive ingredients were enhanced in one direction rather than the other. For instance, the grant would become contractual if a "self-interest" ingredient substitutes the "fondness" ingredient.

In opposition, our proposed view regards the structure as a unit in the sense that it is not simply a balance of ingredients. Rather, it is one ingredient, the motive under focus, that either gains meaning or does not depending on the context. And contexts are discrete: the context of a particular exchange either is aid, contract, and so on. Contexts do not appear as a result of some relative, quantitative blending of some ingredients.

Our proposed view need not mean that a person cannot be involved in more than one structure in one day, or even at once. Even in the same minute, a person could move from one context to another. The same DM could be involved in a market exchange in one instance, while undertakes grant exchange in the succeeding instance-or with a different person simultaneously.

Furthermore, what we think of as archetypal, purely contractual market exchanges may still involve grant-like traces-as when the merchant thanks a customer for their business and offers a gift to express such appreciation. And grant exchanges may involve contract-like traces-as when recipients of the love and affection express their gratitude in terms such as "indebtedness" to the kindness of their supporters-where the debt is the core of duty in the sense that reciprocation has to remain informal.

Still, the core of each structure is different and, hence, contrary to Tönnies each structure is not simply a mix of "ingredients" in different proportions. In the grant context, as in aid context, one should not "pay" for a received gift as though one were paying off a debt. 
It is true that the grant context appears as a mixture of aid and contract. But the camaraderie/grant structure is not simply a middle-way structure, laying somewhere between the altruism/aid, geniality/friendship, and self-interest/contract structures of transactions. The camaraderie/grant structure rather stands independently of the other structures. The grant context is not, to start with, about "interest" in the narrow utilitarian sense. It is rather about the "interest" of wanting to satisfy feelings of camaraderie, to nurture a sense of belonging. This sense arises from a web of social duty-in the sense of informal expectation rather than formal or juridical expectation. If one tries to enforce such solidarity-based duties legally as, for example, if one were to file a legal claim against a brother for failing to show up at one's wedding, the sought-after camaraderie is paradoxically annihilated. The brother has the freedom not to show up for the wedding, and attempting to force him to or to explicitly penalize him with fines for his absence defeats the raison d'être of the duty-based expectation.

On the other hand, the exercise of this freedom, paradoxically, is not free: others would abhor such an exercise of freedom given their concern about solidarity, i.e., maintaining one elemental unit of community, the family. The usual way of enforcing the web of solidarity-based duties is through the practice of "shaming": where the recalcitrant person who fails to perform his social duty is publicly called out, ostracized-even killed, as is the case with so-called "honor killing". So, in this practice of shaming necessitated by the grant context, "private" or "individual" boundaries are blurred: one's business is everyone's business-where the shaming has to be carried out proportionally to the transgression of the duty.

Actually, people may demand institutions of "social control" to enjoy the feeling of belonging or being "at-home" - even when it comes into friction and unease with contract-based obligations, i.e., formal promises that can be legally actionable. It is possible to provide a rational choice account of this demand. The feeling of belonging or being "at-home" certainly allows the person to re-focus and to regenerate his or her human capital, which translates into higher productivity. However, a fully-developed rational choice theory to account for the grant context would fall outside the scope of this paper.

To mention briefly, though, the "impartial spectator," to use Smith's concept again, would judge the readiness of the DM under focus to help others in the community as naïve when others clearly do not reciprocate camaraderie. This is the case when others in one's family or community take advantage of the DM. If the context is market-mediated exchange, the failure to reciprocate leads one simply to cease cooperation with the other or, when justified, to press legal action. But in the camaraderie context, the DM would become bitter in the sense of feeling being exploited, if not ridiculed, by the supposedly family members. So, the rational principle dictates that one should be somewhat careful in extending generosity, not to suppose that others do feel the same extent of generosity. 


\section{Distinction/status}

\subsection{From grant to status}

The classical theorists, from Tönnies to Mauss, highlighted the grant context of exchange, but nevertheless missed one other important context of exchange. Specifically, they failed to see how competition for status, which is rampant with tension, must be distinguished from grant.

Radcliffe-Brown admits that gift-exchange, which is supposed to be the pillar of harmonious solidarity is actually rife with tension. Mauss himself notes at length how gift-exchange may turn into rivalry, as each party or tribe reciprocates with a gift that is clearly greater in value than the gift received earlier. When the returned gift is clearly of greater value, the recipient is challenged. If the recipient reciprocates with an equal high-value gift, the status of the two parties is maintained at parity. If the recipient reciprocates with a lower-value gift, he concedes that he is of a lower status than the original giver. So, gift-exchange fulfils a function that is in addition to grant: it becomes a signal to determine social stratification, or ranking according to status, which is the fundamental element of political power. If the two parties do not agree about what the lines of stratification should be, gift-exchange can become an arms race, as each party competes to establish a higher status and with it greater political power over decisions about the allocation and control of resources. The competition for status, if it does not lead to agreement about the social hierarchy, can lead instead to the disruption of social harmony, to instability, acrimonious relations, and even war.

The grant context, therefore, must be distinguished from a fifth context, the status context. In effect, one failing of Mauss's notion of the gift-exchange is that his conceptual framework fails to delineate between the grant context and the status context. So, a clear articulation of the status context and how it differs from the grant context is imperative to make sense of gift-exchange. The status context is also neither about contract nor about aid — but this should not mean it can be folded into the grant context. Nonetheless, it shares with the grant context the attempt of the DM to seek meaning and to engage in existential decision mode of action: the DM identifies with an imagined self, tries hard to become the imagined self, to experience transcendental utility. While the DM in the grant context attains such a goal by fusing with others, the DM in the status context attains such a goal by fusing with an imagined self. Such imagination amounts to seeking distinction.

As shown next, the quest after distinction engenders a stratified social order, where the distinguished and less distinguished are the constitutive parties of an authority relation. Such a relation is similar to the other structures of the transcendental mode, mediated by gift-exchange.

Note, the gift-exchange in the status context fulfils a function that differs from the gift-exchange function in grant-giving that expresses communal solidarity. Namely, the gift-exchange in the grant context reassures one's bonding with the community, generating solidarity. The gift-exchange in the status context allows some DMs to express distinction from and if excessive, even superiority over others, while the 
subordinates derive comfort, pride, and security from their association with the powerful DMs. So, the status context can be seen as essential to political order, which cannot be detailed here.

\subsection{Distinction and conspicuous consumption}

Parties within the grant context are symmetrical in status vis-à-vis each other as is the case with members of the same family. In contrast, parties engaging in exchanges within the status context stand asymmetrically to each other, where some exercise political power, i.e. authority, over their lower status counterparts. DMs attain authority when they achieve a certain distinction in one dimension or another-whereas less successful DMs look up and admire the distinguished others along the dimension that is important and worthwhile for them. In a society for which horse riding is crucial, for example, the best riders gain authority. In a society for which the accumulation of wealth is most important, the wealthiest amass authority. Philanthropy — as well as being an expression of aid-is a way in which people display their high status and, hence, exercise authority (Khalil 2004).

Another way to express distinction and to display status is for the successful DMs to offer gifts to the less successful ones. Here the gift-exchanges, to act as signals of status, have to be extravagant and not reciprocated by gifts of equal value. When the ranking order is stable, the different parties tacitly consent to the fact that one party is more prestigious than the others, and hence its "generosity" cannot be reciprocated. Then, the other parties must submit to the authority of the more "generous" party. Otherwise, as Mauss witnessed, gift exchanges lead to an unstable social structure where the competition for status can become fierce.

In fact, for status competition to operate, it is not necessary that the DM showers gifts on another. It can equally proceed when the DM showers gifts on him- or herself-what Thorstein Veblen (1934) calls “conspicuous consumption". Veblen's observation did not stem from anthropological field study of some exotic tribe, but rather from anthropological study of American society towards the end of the nineteenth century. The undertaking of conspicuous consumption or the immersion into luxury fever is nothing other than the "destruction" of wealth in the narrow utilitarian sense. The destruction is definitely escalated when the other party retaliates or when the competition for positional goods is fierce (Frank 1985, 2011). However, the origin of the destruction is not the arms-race itself. Let us assume that the original giver, motivated by status, showers the other or showers himself with goods that are aimed to buttress his status vis-à-vis the other. If the other does not compete, i.e. if the other surrenders, there will be no arms race. But still the original conspicuous consumption geared for status gain amounts to the destruction of wealth. The seeker of the higher status would not have consumed these goodswasted such wealth - if the seeker were behaving as a Robinson Crusoe, i.e., if there is no status to pursue. But it is still feasible to think that even a Robinson Crusoe seeks distinction once we recognize that the desire of the DM for distinction and, 
corollary, for the celebration of accomplishment is not fully based on the applause of others. ${ }^{7}$

Still, the DM must use rational choice in choosing the degree or extent of aspiration, the desire for distinction. The "impartial spectator," to use Smith's concept again, would judge the intensity of the desire to succeed and distinguish the self as excessive if the intensity engenders more misery than pleasure at the margin. While aspiring is part of the human condition, it could lead to unhappiness if not regulated rationally (see Khalil 2020b). One great pillar of happiness is the optimal balance between the satisfaction from aspiring, on one hand, and the sense of deficiency that arises from the gap between the goal and actual status, on the other. The sense of deficiency that may lead to great misery is endemic of aspiring since aspiration, by definition, means desiring an end that one does not have.

\section{Conclusion}

Adam Smith proposed a twofold taxonomy of structures of exchange that are focused on corporeal utility: the self-interest/contract structure and the altruism/aid structure. The object of this paper is to highlight at least three more structures of exchange that involve transcendental utility: the geniality/friendship structure, camaraderie/grant structure, and the distinction/status structure.

There is a reason why rational choice theorists have overlooked these three structures. These three structures are usually sustained by gift exchange. Although the gift-exchange takes different meaning depending on the context of the exchange, the gift-exchange in all three contexts allows the DM to engage in non-instrumental, existential rational mode of action. In contrast, in the contact context and aid context, the DM engages in instrumental decision mode of action. To make sense of the difference, this paper appeals to Martin Buber's dialogical approach: while the existential decision mode allows the DM to transcend the self to acquire meaning of one's life, the instrumental rational decision mode allows the DM to sustain the corporeal interest, whether pecuniary self-interest or pecuniary other-interest (altruism).

Acknowledgements We appreciate the comments of Elizabeth Anderson, James Andreoni, Amitai Etzioni, Jonathan Wight, Birendra Rai, Phillip Krohn, Steven Gardner, anonymous reviewers, and the editorial help of Maks Sipowicz. The usual caveat applies.

\footnotetext{
7 Status consumption is about the enjoyment of distinction or prominence achieved and, hence, should not be modeled, contrary to Becker et al. (2005), as equivalent to the consumption of ordinary, substantive goods. For Becker et al., the DM substitutes smoothly, in the same utility function, between normal goods and status goods. So, as the DM burns normal goods, spectators accord him status. This need not be the case if spectators start to do the same. We end up with so much destroyed wealth, with no one above the other in social ranking. Further, thinking of status goods as similar to normal goods is somehow "strange". If the DM burns all his normal goods, in order to gain status goods, he would be putting all his wealth in a fancy automobile, which he can parade, but has to hide the fact that he has no home or any other goods. But if these facts were revealed, his status would plummet. So, status goods are rather symbolic of one's true prominence or distinction: A person may not be able, even if he tries, to buy symbolic utility to start with (see Khalil 2000).
} 
Open Access This article is licensed under a Creative Commons Attribution 4.0 International License, which permits use, sharing, adaptation, distribution and reproduction in any medium or format, as long as you give appropriate credit to the original author(s) and the source, provide a link to the Creative Commons licence, and indicate if changes were made. The images or other third party material in this article are included in the article's Creative Commons licence, unless indicated otherwise in a credit line to the material. If material is not included in the article's Creative Commons licence and your intended use is not permitted by statutory regulation or exceeds the permitted use, you will need to obtain permission directly from the copyright holder. To view a copy of this licence, visit http:// creativecommons.org/licenses/by/4.0/.

Funding Open Access funding provided by the Qatar National Library.

\section{References}

Andreoni, J. (1988). Why free ride? Strategies and learning in public goods experiments. Journal of Public Economics, 37, 291-304.

Becker, G. S. (1981). Altruism in the family and selfishness in the market place. Economica, 48, 1-15.

Becker, G. S. (1993). Nobel lecture: The economic way of looking at behavior. Journal of political economy, 101(3), 385-409.

Becker, G. S., Murphy, K. M., \& Werning, I. (2005). The equilibrium distribution of income and the market for status. Journal of Political Economy, 113, 282-310.

Blau, P. M. (1974). On the nature of organizations. New York: Wiley.

Boulding, K. E. (1973). The economy of love and fear. Belmont: Wadsworth.

Boulding, K. E. (1982). A preface to grants economics: The economy of love and fear. New York: Praeger.

Bowles, S., \& Gintis, H. (2002). Social capital and community governance. Economic Journal, 112, 419-436.

Bowler, W. M., \& Brass, D. J. (2006). Relational correlates of interpersonal citizenship behavior: A social networks perspective. Journal of Applied Psychology, 91, 70-82.

Brief, A. P., \& Motowidlo, S. J. (1986). Prosocial organizational behaviors. Academy of Management Review, 11(4), 710-725.

Bruni, L., \& Sugden, R. (2008). Fraternity: Why the market need not be a morally free zone. Economics \& Philosophy, 24, 35-64.

Buber, M. (1970). I and Thou trans. Walter Kaufmann 1923. New York: Scribner's Sons.1923

Cedrini, M. A., Ambrosino, A., Marchionatti, R., \& Caillé, A. (2019). Mauss's The Gift, or the necessity of an institutional perspective in economics. Journal of Institutional Economics. https://doi.org/10. 1017/S1744137419000687.

Coleman, J. S. (1990). Foundations of social theory. Cambridge: Harvard University Press.

Darwall, S. (2011). Being with. Southern Journal of Philosophy, 49(s1), 4-24.

De Dreu, C. K. W. (2006). Rational self-interest and other orientation in organizational behavior: A critical appraisal and extension of Meglinoand Korsgaard (2004). Journal of Applied Psychology, 91(6), 1245-1252.

De Dreu, C. K. W., \& Nauta, A. (2009). Self-interest and other- orientation in organizational behavior: Implications for job performance, prosocial behavior, and personal initiative. Journal of Applied Psychology, 94, 913-926.

Dyrenfurth, N. (2015). Mateship: A very australian history. Melbourne: Scribe.

Ehrhart, M. G., \& Naumann, S. E. (2004). Organizational citizenship behavior in work groups: A group norms approach. Journal of Applied Psychology, 89, 960-974.

Eisen, A. (1978). The meanings and confusions of Weberian 'rationality'. British Journal of Sociology, 29(1), 57-70.

Etzioni, A. (1986). The case for a multiple-preference conception. Economics and Philosophy, 2, $159-183$.

Etzioni, A. (1988). The moral dimension: Toward a new economics. New York: Free Press. 
Folbre, N., \& Nelson, J. A. (2000). For love or money-or both? Journal of Economic Perspectives, 14, $123-140$.

Frank, R. H. (1985). Choosing the right pond. New York: Oxford University Press.

Frank, R. H. (2011). The Darwin economy: Liberty, competition, and the common good. Princeton: Princeton University Press.

Frey, B. (1997). Not just for the money: An economic theory of personal motivation. Cheltenham: Elgar.

Granovetter, M. (1973). The strength of weak ties. American Journal of Sociology, 78(6), 1360-1380.

Granovetter, M. (1983). The strength of weak ties: A network theory revisited. Sociological Theory, 1, 201-233.

Granovetter, M. (2005). The impact of social organization on economic outcomes. Journal of Economic Perspectives, 19(1), 33-50.

Grant, A. M. (2008). The significance of task significance: Job performance effects, relational mechanisms, and boundary conditions. Journal of Applied Psychology, 93, 108-124.

Gui, B. (1996). On relational goods: Strategic implications of investment in relationships. International Journal of Social Economics, 23, 260-278.

Gui, B. (2000). Beyond transactions: On the interpersonal dimension of economic reality. Annals of Public and Cooperative Economics, 71, 139-169.

Gui, B., \& Sugden, R. (Eds.). (2010). Economics and social interaction: Accounting for interpersonal relations. Cambridge: Cambridge University Press.

Guiso, L., Sapienza, P., \& Zingales, L. (2004). The role of social capital in financial development. American Economic Review, 9(3), 526-556.

Guiso, L., Sapienza, P., \& Zingales, L. (2006). Does culture affect economic outcomes? Journal of Economic Perspectives, 20(2), 23-48.

Hart, K. (2007). Marcel Mauss: In pursuit of the whole. A review essay. Comparative Study in Society and History, 49(2), 1-13.

Hodgson, G. M. (2000). What is the essence of institutional economics? Journal of Economic Issues, 34(2), 317-329.

Hodgson, G. M. (2003). The hidden persuaders: institutions and individuals in economic theory. Cambridge Journal of Economics, 27(2), 159-175.

Hodgson, G. M. (2006). What are institutions? Journal of economic issues, 40(1), 1-25.

Homans, G. C. (1961). Social behavior: Its elementary forms. New York: Harcourt Brace and World.

Katz, S. (1985). Post-holocaust dialogues. New York: New York University Press.

Khalil, E. L. (1990). Beyond self-interest and altruism: A reconstruction of Adam Smith's theory of human conduct. Economics \& Philosophy, 6(2), 255-273.

Khalil, E. L. (1996). Respect, admiration, aggrandizement: Adam Smith as economic psychologist. Journal of Economic Psychology, 17(5), 555-577.

Khalil, E. L. (2000). Symbolic products: Prestige, pride and identity goods. Theory and Decision, 49(1), 53-77.

Khalil, E. L. (Ed.). (2003). Trust. Cheltenham: Edward Elgar.

Khalil, E. L. (2004). What is altruism? Journal of Economic Psychology, 25, 97-123.

Khalil, E. L. (2012). Why Europe? A critique of institutionalist and culturalist economics. Journal of Economic Surveys, 26(2), 351-372.

Khalil, E. L. (2017). Socialized view of man vs. rational choice theory: What does Smith's sympathy have to say? Journal of Economic Behavior and Organization, 143, 223-240.

Khalil, E. L. (2020a). Why is the commodification of friendship-and-love repugnant? A theory of preferences via The Theory of Moral Sentiments. (under review)

Khalil, E. L. (2020b). Solving the wellbeing-happiness puzzle. Erasmus Journal for Philosophy and Economics. (under revise-and-resubmit)

Khalil, E. L., \& Marciano, A. (2018). A theory of tasteful and distasteful transactions. Kyklos, 71(1), $110-131$.

Khalil, E. L., \& Marciano, A. (2021). Other-regarding preferences: The poverty of the self/other dichotomy. Social Theory and Practice: An International and Interdisciplinary Journal of Social Philosophy, 47(1). (forthcoming)

Kreps, D. M. (2013). Microeconomic foundation I: Choice and competitive markets. Princeton: Princeton University Press.

Malinowski, B. (1922). Argonauts of the Western Pacific: An account of native enterprise and adventure in the Archipelagoes of Melanesian New Guinea. London: Routledge and Kegan Paul. 
Mauss, M. (1990). The gift: Forms and functions of exchange in archaic societies. Foreword by Mary Douglas. London: Routledge.

Meglino, B. M., \& Korsgaard, M. A. (2004). Considering rational self-interest as a disposition: Organizational implications of other orientation. Journal of Applied Psychology, 89(6), 946-959.

Meglino, B. M., \& Korsgaard, M. A. (2006). Considering situational and dispositional approaches to rational self-interest: An extension and response to De Dreu (2006). Journal of Applied Psychology, 91(6), 1253-1259.

Michel, J. W. (2017). Antecedents of organizational citizenship behaviors: Examining the incremental validity of self-interest and prosocial motives. Journal of Leadership \& Organizational Studies, 24(3), 385-400.

Nelson, J. A. (2005). Interpersonal relations and economics: Comments from a feminist perspective. In B. Gui \& R. Sugden (Eds.), Economics and social interaction: Accounting for interpersonal relationships (pp. 250-261). Cambridge: Cambridge University Press.

Putnam, R. D. (1993). Making democracy work: Civic traditions in modern Italy. Princeton: Princeton University Press.

Putnam, R. D., \& Alone, B. (2000). The collapse and revival of American community. New York: Simon and Schuster.

Rocha, H. O., \& Ghoshal, S. (2006). Beyond self-interest revisited. Journal of Management Studies, 43(3), 585-619.

Schilpp, P. A. (Ed.). (1967). The philosophy of Martin Buber (Library of living philosophers). La Salle: Open Court.

Smith, A. (1976a). The theory of moral sentiments, eds. D.D. Raphael and A.L. Macfie. Oxford: Oxford University Press.

Smith, A. (1976b). Inquiry into the nature and causes of the wealth of nations, in 2 volumes, general editors R.H. Campbell and A.S. Skinner, textual editor W.B. Todd. Oxford: Oxford University Press.

Spencer, L. \& Pahl, R. E. (2006). Rethinking friendship: Hidden solidarities today. Princeton: Princeton University Press.

Sugden, R. (2002). Beyond sympathy and empathy: Adam Smith's concept of fellow-feeling. Economics and Philosophy, 18, 63-87.

Sugden, R. (2005). Correspondence of sentiments: An explanation of the pleasure of social interaction. In L. Bruni \& P. L. Porta (Eds.), Economics and happiness: framing the analysis, (pp. 91-115). Oxford: Oxford University Press.

Suttles, G. D. (1970) The social order of the slum: Ethnicity and territory in the inner city. Chicago: University of Chicago Press.

Tasselli, Stefano (2019). Love and organization studies: Moving beyond the perspective of avoidance. Organization Studies, 40(7), 1073-1088.

Tönnies, F. (2001). Community and Civil Society, J. Harris (Ed.), trans. Jose Harris and Margaret Hollis. Cambridge: Cambridge University Press.

Veblen, T. (1934). The theory of the leisure class. New York: Modern Library.

Ward, R. (1958). The australian legend. Melbourne: Oxford University Press.

Weber, M. (1978). Economy and Society, G. Roth., \& C. Wittich. (Ed.). Berkeley: University of California Press.

Wood, R. (1969). Martin Buber's ontology: An analysis of "I and thou”. Evanston: Northwestern University Press.

Wray, L. R. (1994). Kenneth Boulding's grants economics. Journal of Economic Issues, 28(4), 1205-1225.

Wyschogrod, M. (1967). Martin Buber. The Encyclopedia of Philosophy, ed. Paul Edwards 1. New York: Macmillan.

Publisher's Note Springer Nature remains neutral with regard to jurisdictional claims in published maps and institutional affiliations. 


\section{Affiliations}

\section{Elias L. Khalil ${ }^{1}$ (D) Alain Marciano ${ }^{2}$}

$\triangle$ Elias L. Khalil

elias.lafi.khalil@gmail.com

Alain Marciano

alain.marciano@umontpellier.fr

1 School of Public Administration and Development Economics, Doha Institute for Graduate Studies, Zone 70, Al Tarfa Street, PO Box 200592, Al Daayen, Qatar

2 MRE and Department of Economics, University of Montpelier, Montpelier, France 